\title{
ELECTROCARDIOGRAPHIC CHANGES IN MIGRAINE
}

\author{
Tahaseenbanu Shaikh*, Shaktiprasad Hiremath** \\ *Tutor in Department of Physiology, BIMS, Belagavi, ** Assistant Professor in Department of Physiology, KIMS, Hubli
}

Background: Migraine is the second most common cause for Primary headache. Migraine often results in considerable disability and decrease in the patients' quality of life. Its prevalence is highest in the age group of 25 - 55 years, which are the peak years of economic productivity. In literature autonomic nervous system (ANS) impairment in migraine is well documented i.e. migraine is of neural origin. Also autonomic dysfunction in migraine may also affect autonomic innervation of the heart resulting in ECG changes. Objectives: To study ECG changes in patients of migraine. Materials and methods: Thirty migraine female patients aged 25 to 55 were included. Thirty age and gender matched controls were chosen for comparison. In all the study subjects and controls, resting ECG was recorded. Statistical analysis was done by unpaired student ' $t$ ' test. Results: The resting heart rate was found to be significantly higher in migraineurs compared to controls $(P<0.05)$. QTc interval although was within the normal range, it was significantly more $(P<0.01)$ in migraineurs when compared to controls Interpretation and conclusion: ECG changes were found in migraineurs which indirectly suggest disturbed autonomic innervation to heart.

Key Words: P wave dispersion ; Electrocardiographic changes ; Migraine.

Author for correspondence: Dr. Shaktiprasad Hiremath, Department of Physiology, Karnataka Institute of Medical Sciences, Hubli, Karnataka-580021 e- mail: kimshubliphysiology@gmail.com

\section{Introduction:}

It has been proposed that both sympathetic and parasympathetic dysfunctions have played important roles in the pathophysiology of migraine. ${ }^{1}$ Disturbance of autonomic nervous system may affect atrial and ventricular repolarization of heart. Thus disturbance in the autonomic innervation of heart in patients with migraine may also result in possible electrocardiographic manifestations. ${ }^{2}$

\section{Material and Methods:}

In this study data was collected from thirty migraine patients diagnosed according to Headache Classification Committee of the International Headache Society 2004, ${ }^{3}$ in the age group of 25 to 55 years, attending Neurology OPD. Thirty age and gender matched controls were selected. The following inclusion and exclusion criteria were applied for selection process:

i) Inclusion criteria:

Subjects aged between 25 and 55 years, who report of headache lasting 4 to 72 hours with normal physical examination and are diagnosed as having migraine by a Neurophysician along with at least two of the following features:

1. Unilateral pain

2 Throbbing pain

3 Aggravated by movement
4 Moderate or severe intensity

Plus at least one of the following features:

1. Nausea/ vomiting

2. Photophobia and phonophobia

(Adapted from the Headache Classification Committee of International Headache Society, $2004)^{3}$

ii) Exclusion criteria:

1. Upper respiratory tract infections

2. Meningitis

3. Intracranial hemorrhage

4. Intracranial tumors

5. Temporal arteritis

6. Glaucoma

7. Any condition associated with ANS dysfunction like Diabetic neuropathy, familial dysautonomias, drugs affecting ANS (beta blockers etc), and tobacco abuse either smoking or chewing.

ECG recording in migraineurs: 
ECG was recorded in supine position after a rest period of $10 \mathrm{~min}$, AUTO mode in the instrument was selected and the following parameters were noted in migraineurs and controls: Resting heart rate (beats / min), PR interval (ms), P wave (ms), QRS (ms), T wave (ms), QT interval (ms), QTc interval (ms), $P$ axis (degrees), QRS axis (degrees), $T$ axis (degrees), $P$ wave dispersion (in $\mathrm{ms}$ ). $\mathrm{P}$ wave dispersion was calculated by noting the $P$ wave duration in all the 12 leads. $P$ wave duration was measured by scanning the ECG paper at $600 \mathrm{dpi}$ resolution and accurate measurement of $P$ wave duration in all leads was noted down. The difference between the maximum and minimum duration was taken. Mean and standard deviation were calculated for all parameters. The statistical analysis was done using student ${ }^{\prime} \mathrm{t}$ ' test. A probability ' $P$ ' value of $<0.05$ was considered as significant(S), probability ' $P$ ' value of $<0.01$ was considered as highly significant (HS) and a probability ' $P$ ' value of $<0.001$ was considered as very highly significant (VHS). Graph pad cloud software was used for analysis.

\section{Result:}

The following ECG parameters: QTc interval and QRS axis showed significant difference between controls and migraine subjects. QTc interval, although within the normal range, was longer significantly in migraine subjects as compared to the controls and QRS axis (in degrees) was significantly less in migraine subjects as compared to the controls. The resting heart rate in migraineurs was significantly higher than in controls. This may indicate a slight parasympathetic hypo-activity or sympathetic hyperactivity.

\begin{tabular}{|c|c|c|c|c|}
\hline Parameters & $\begin{array}{c}\text { Controls } \\
\text { (mean } \pm \text { SD) }\end{array}$ & $\begin{array}{c}\text { Subjects } \\
\text { (mean } \pm \text { SD) }\end{array}$ & $\begin{array}{c}\text { 't' } \\
\text { value }\end{array}$ & $\begin{array}{c}\text { 'P' } \\
\text { value }\end{array}$ \\
\hline $\begin{array}{c}\text { PR interval } \\
\text { (ms) }\end{array}$ & $139.97 \pm 14.79$ & $144.27 \pm 22.02$ & 0.887 & $\begin{array}{c}0.378 \\
\text { (NS) }\end{array}$ \\
\hline P wave (ms) & $106.4 \pm 9.15$ & $107.83 \pm 8.85$ & 0.616 & $\begin{array}{c}0.539 \\
\text { (NS) }\end{array}$ \\
\hline $\begin{array}{c}\text { QRS } \\
\text { complex } \\
\text { (ms) }\end{array}$ & $76.57 \pm 6.22$ & $79.57 \pm 6.40$ & 1.84 & $\begin{array}{c}0.07 \\
\text { (NS) }\end{array}$ \\
\hline $\begin{array}{c}\text { T wave (ms) } \\
\text { wave }\end{array}$ & $161.23 \pm 15.37$ & $163.47 \pm 15.62$ & 0.558 & 0.578 \\
(NS)
\end{tabular}

Table No1. Anthropometric data

Table No 2 PR interval (ms), P wave (ms), QRS

\begin{tabular}{|c|c|c|c|c|}
\hline Parameters & $\begin{array}{c}\text { Controls } \\
\text { (mean } \pm \text { SD) }\end{array}$ & $\begin{array}{c}\text { Subjects } \\
\text { (mean } \pm \text { SD) }\end{array}$ & ' $\mathbf{t}^{\prime}$ & ' $\mathbf{P}$ ' \\
value \\
\hline $\begin{array}{c}\text { QT interval } \\
\text { (ms) }\end{array}$ & $361.47 \pm 22.06$ & $360.57 \pm 22.81$ & 0.145 & $\begin{array}{c}0.885 \\
\text { (NS) }\end{array}$ \\
\hline $\begin{array}{c}\text { QTc } \\
\text { interval } \\
\text { (ms) }\end{array}$ & $402.13 \pm 21.03$ & $416.33 \pm 16.44$ & 2.91 & $\begin{array}{c}0.005 \\
\text { (HS) }\end{array}$ \\
\hline $\begin{array}{c}\text { P wave } \\
\text { dispersion } \\
\text { (ms) }\end{array}$ & $45.33 \pm 13.19$ & $47.33 \pm 16.49$ & 0.519 & 0.605 \\
(NS) \\
\hline
\end{tabular}

complex (ms) and T wave (ms)

Table No. 3. QT interval (ms), QTc interval (ms) and

$P$ wave dispersion (ms)

\section{Discussion:}

ECG changes in migraineurs:

\begin{tabular}{|l|l|l|l|l|}
\hline $\begin{array}{l}\text { Param } \\
\text { eters }\end{array}$ & $\begin{array}{l}\text { Controls } \\
\text { (mean } \pm \text { SD) }\end{array}$ & $\begin{array}{l}\text { Subjects } \\
\text { (mean } \pm \\
\text { SD) }\end{array}$ & 't' value & 'P' value \\
\hline $\begin{array}{l}\text { Age } \\
\text { (years) }\end{array}$ & $26.83 \pm 4.04$ & $28.57 \pm 5.44$ & 1.467 & $0.14(\mathrm{NS})$ \\
\hline $\begin{array}{l}\text { Height } \\
(\mathrm{cm})\end{array}$ & $153.1 \pm 7.09$ & $153.8 \pm 5.38$ & 0.429 & $0.668(\mathrm{NS})$ \\
\hline $\begin{array}{l}\text { Weight } \\
(\mathrm{kg})\end{array}$ & $48.53 \pm 6.84$ & $51.23 \pm 7.76$ & 1.45 & $0.152(\mathrm{NS})$ \\
\hline $\begin{array}{l}\mathrm{BMI} \\
\left(\mathrm{kg} / \mathrm{m}^{2}\right)\end{array}$ & $20.74 \pm 2.98$ & $21.52 \pm 3.21$ & 1.01 & $0.314(\mathrm{NS})$ \\
\hline
\end{tabular}


The following ECG parameters were noted in migraineurs and controls:-

Resting heart rate(beats / min), PR interval (ms), P wave (ms), QRS complex (ms), T wave (ms), QT interval (ms), QTc interval (ms), P axis (degrees), QRS axis (degrees), $T$ axis (degrees), $P$ wave dispersion (in ms).

There was significant difference in QTC interval and QRS axis between migraineurs and controls. The other remaining parameters did not show any statistically significant difference between migraineurs and controls:

The QTc interval of migraineurs was $416.33 \pm$ 16.44 milliseconds and that of controls was 402.13 \pm 21.03 milliseconds. Thus although the QTc interval was within the normal range in migraineurs, it was significantly more in migraineurs when compared to the controls.

$M$ Duru et al In their study they have discovered significantly increased QTc interval in migraineurs along with increased QTc dispersion and increased $P$ wave dispersion during migraine attacks. ${ }^{4}$

Aygun et al has also reported increased QTC and PR intervals during migraine attacks compared with pain free periods ${ }^{5}$ It has been reported that dysfunction of the ANS influences ventricular repolarization and, therefore, increases the QT interval on the ECG. ${ }^{6}$

The QT interval reflects depolarization and repolarization of myocardial cells. Factors that augment depolarization or delay repolarization of myocardial cells can increase QT interval length. Genetic factors and non-genetic factors such as electrolyte disturbances and drugs influence the QTc.

There is indirect evidence that the autonomic nervous system activity also influences QTC.

QTc is prolonged in patients with diabetic autonomic neuropathy ${ }^{7}$ and in familial dysautonomia patients. ${ }^{8}$

Similarly, QTc is increased in patients with primary autonomic failure due to pure autonomic failure or multiple system atrophy. ${ }^{9}$

It has been reported that prolonged QT intervals appear to correlate with the severity of autonomic dysfunction in various diseases, such as diabetes mellitus. $^{7}$

Also manipulation of the autonomic nervous system in experiments demonstrated the influence of imbalanced sympathetic activity on heterogeneity of repolarization in the myocardium, resulting in QT interval prolongation. ${ }^{10,11}$

Further studies have shown that a prolonged QT interval and $\mathrm{P}$-wave dispersion in the pain-free period can be predictors of atrial and ventricular arrhythmias.4, 6

These findings may reflect atrial and ventricular repolarization abnormalities that are affected by a disturbed ANS.

\section{Conclusion:}

QTc interval is found to be significantly more in migraineurs when compared to the controls suggesting disturbed autonomic innervation to the heart.

\section{References:}

1. Havanka-Kanniainen H, Tolonen U, Myllyla VV. Autonomic dysfunction in migraine: a survey of 188 patients. Headache 1988; 28: 465-70.

2. A .Kocer, M .Erylmaz, H.Tutkan et al. Higher Pwave dispersion in migraine patients with higher number of attacks. The Scientific World Journal, Volume 2012(2012), Article ID 791460, 4 Pages, DOI: 10 1100/2012/791460.

3. Headache classification Committee of the International Headache Society. The International Classification of Headache Disorders: 2nd edition, Cephalalgia, vol. 24, supplement 1, pp. 1-160, 2004

4. M Duru, I Melek, E Seyfeli, T Duman, G Kuvandık, H Kaya and F Yalcın: QTc dispersion and $P$-wave dispersion during migraine attacks. Cephalalgia. 2006 June;26(6):672-677.

5. Aygun D, Altintop L, Doganay $Z$ et al: Electrocardiographic changes during migraine attacks. Headache, 2003; 43: 861-66.

6. Schouten EG, Dekker JM, Meppelink P et al: QT interval Prolongation predicts cardiovascular mortality in a apparently healthy population. Circulation, 1991; 84:1516-23.

7. Bellavere F, Ferri M, Guarini L, Bax G, Piccoli A, Cardone C, Fedele D: Prolonged QT period in diabetic autonomic neuropathy: a possible role in sudden cardiac death? $\mathrm{Br}$ Heart J. 1988; 59:379-383.

8. Glickstein JS, Schwartzman D, Friedman D, Rutkowski M, Axelrod FB. 
Abnormalities of the corrected QT interval in familial dysautonomia: an indicator of autonomic dysfunction. J Pediatr1993; 122:925-928.

9. Lo SS, Mathias CJ, Sutton MS. QT interval and dispersion in primary autonomic failure. Heart 1996; 75:498-501.

10. Kahima $\mathrm{T}$, Tamaka $\mathrm{H}$, Minagoe $\mathrm{S}$, Toda $\mathrm{H}$ : Electrocardiographic changes induced by the stellate ganglion block in normal subjects. J Electrocardiol 1981; 14:169-174.

11. Schwartz PJ, Snebold NG, Brown AM: Effects of unilateral cardiac sympathetic denervation on the ventricular fibrillation threshold. Am J Cardiol 1976; 37: 10351040.

Disclosure: No conflicts of interest, financial, or otherwise are declared by authors 